\title{
ANALISIS KEMAMPUAN KONEKSI MATEMATIS PESERTA DIDIK KELAS V SD MELALUI PMR DAN BENTUK PORTOFOLIO
}

\author{
Nadar $^{1}$, Syaparuddin ${ }^{2}$, Masnur $^{3}$ \\ ${ }^{1}$ (Primary School Teacher Education Department,/University Muhammadiyah Enrekang, Indonesia). \\ ${ }^{2}$ (Primary School Teacher Education Department,/University Muhammadiyah Enrekang, Indonesia). \\ ${ }^{3}$ (Primary School Teacher Education Department,/University Muhammadiyah Enrekang, Indonesia). \\ * Corresponding Author. E-mail: adhar.dikdas14@gmail.com, masnur1985@gmail.com
}

\begin{abstract}
Receive: 10/09/2020
Accepted: $10 / 10 / 2020$

Published: 30/10/2020

Abstrak

Tujuan penelitian ini adalah 1) Untuk mendeskripsikan kemampuan koneksi matematis peserta didik melalui pendekatan pembelajaran matematika realistik dengan Bentuk Portofolio. Metode yang digunakan dalam penelitian ini adalah metode deskriptif dengan menggunakan pendekatan dekriptif kualitatif. Subjek penelitian ini adalah seluruh peserta didik kelas V SDN 8 Pinrang. Teknik pengumpulan data yang akan dilakukan melalui teknik tes, observasi partisipatif, wawancara mendalam dan dokumentasi dengan Instrumen utamanya adalah Peneliti dan ditambah dengan instrumen bantu berupa lembar penilaian, lembar observasi dan pedoman wawancara. Teknik analisis data di lakukan yaitu data reduction, data display dan conclusion drawing/verification. Hasil penelitian ini terdapat kemampuan koneksi matematis peserta didik melalui pendekatan pembelajaran matematika realistik baik penilaian dilakukan dengan portofolio tampilan maupun portofolio dokumentasi.
\end{abstract}

Kata Kunci: Koneksi Matematis, Pendidikan Matematika Realistik, Bentuk Portofolio

\section{Pendahuluan}

Koneksimatematismerupakankemam puan dasaryangharusdimilikipesertadidik sehinggamampu menghadapi permasalahan baikdalampembelajaran matematikamaupun dalam kehidupan nyata. National Council of Teacher of Mathematics (NCTM) (2000: 64) mengemukakan bahwawhen student can connect mathematical ideas, their understanding is deeper and more lasting. Dengan kata lain, peserta didik dapat mengaitkan antar konsepyang telah diketahuinya dengan konsep baru dengan menghubungkan suatu konsep dengan kehidupan sehari-hari. Sejalan yang dikemukakan oleh Wahyudin (2008) bahwa kemampuan koneksi bukan hanya kemampuanyang diajarkandan digunakan dalam matematika,tetapi lebih dari itukemampuankoneksimerupakanketerampila ndalammenghadapi masalah dalam kehidupan sehari-hari. Dengan adanya keterkaitan antara kehidupan sehari-hari dengan materi pelajaran yangakan dipelajari peserta didik akan menambah pemahaman dalam belajarmatematika.

Kemampuan peserta didik dalam mengaitkan antar topik matematika dengan dunia nyatadinilai sangat penting, karenadapat membantu peserta didikdalam memahami topik-topik yang ada dalam matematika. Hal ini senada yang dikemukakan oleh Linto, dkk, (2012:83) bahwa koneksi matematis penting dimiliki peserta didik karena dapat menghubungkan sebuah materi dengan materi lainya,dapat memahamikonsep matematika yang mereka pelajari karena mereka telah meguasai materi prasayaratyangberkaitandengan kehidupan sehari-hari, selain mampu mengaitkan materi yang mereka pelajari dengan pokok bahasan sebelumnya atau dengan 
matapelajaran lain, sehingga membuat pembelajaran matematika menjadi lebih bermakna.Oleh karena itu diperlukan adanya peningkatan kemampuan koneksi matematis dalam pembelajaran matematika karena topik-topik dalam matematika banyak memiliki relevansi dan manfaat dengan bidang lain, baik di sekolah maupun di luar sekolah.

Namun kenyataannya pengembangan kemampuan koneksi matematika belum optimal. Hal ini berdasarkan data awal peneliti yang dilakukandiUPT SDN 8 Pinrang, menunjukkan bahwa peserta didik mengalami beberapa kesulitan dalam menyelesaikan soal terkait menuliskan masalah kehidupan sehari-hari kedalam bentuk model matematika, menghubungkan antar obyek dan konsep dalam matematika, dan dalam menentukan rumus apa yang akan dipakai jika dihadapkan pada soal-soal yang berkaitandengan masalah kehidupan seharihari.

Berdasarkan permasalah tersebut, perlu dilakukan perbaikan terhadap pembelajaran matematikaterkait kemampuan koneksi matematis di SD. Tentunya perlu mempertimbangkan pendekatan yang cock tahap perkembangangan peserta didik mengingat cara berpikir dan kekuatan mentalnya yang berbeda (Masnur, 2017: 40). Oleh karena itu guru harus mampu meningkatkankemampuan koneksi matematispeserta didik dengan menggunakan pendekatan pembelajaran matematika realistik (PMR).

Crompton \& Traxler (2015, p. 97) menjelaskan bahwa $R M E$ is an approach to mathematics education that involves students developing their understanding by exploring andsolving problem set in contexts that engage their interest.Dengan kata lain bahwa pendekatan ini memperhatikan ketertarikan peserta didik melalui kegiatan eksplorasi dan memecahkan masalah dalam mengembangkan pemahaman matematika.

Kusmoyono (2013: 107) menjelaskan bahwa pada dasarnya pendidikan matematikarealistik adalah pemanfaatan lingkungan yang dipahami peserta didik untuk memperlancarproses pembelajaran matematika, sehingga mencapai tujuan pendidikan matematika yang lebihbaik. Dengan memanfaatkan lingkungan dimana peserta didik berada akanlebih mudah dipahami oleh peserta didik.

$$
\text { Treffers (Wijaya, 2012: }
$$

merumuskan lima karakteristikPMR yaitu, (1) Penggunaan konteks "Dunia Nyata"; (2) Penggunaan model untukmengkontruksi konsep; (3) Pemanfaatan hasil kontruksi siswa; (4) Interaktivitas; (5) Keterkaitan.Dari lima karakteristik pendidikan matematika realistik dapat disimpulkan bahwa apabila peserta didik dilibatkan dalamkegiatan belajar tersebut dengan menghubungkan dunia nyata berupa alat dalam bentuk permainan,penggunaan alat peraga, atau situasi lain selama, maka dapat menambah pemahaman mereka terhadap matematika dalam mengembangkan dana mengarahkan pada pengkonstruksian berbagaiprosedur dalam memecahkan masalah.Dengan demikian pemanfaatan interaksi dalampembelajaran matematika bermanfaat dalam mengembangkan kemampuan kognitif dan afektif peserta didik secara simultan.

$$
\text { Paradigma baru pendidikan }
$$

matematika menghendaki dilakukaninovasi yang terintegrasi dan berkesinambungan. Salah satu wujudnya adalahinovasi yang dilakukan guru dalam kegiatan pembelajaran dan penilaian dikelas. Kebiasaan guru dalam kegiatan mengumpulkan informasi mengenaitingkat pemahaman peserta didik melalui pertanyaan, observasi, pemberiantugas dan tes akan sangat bermanfaat dalam menentukan tingkat penguasaanpeserta didik dan dalam evaluasi keefektifan proses pembelajaran danpenilaian. Hal ini yang penting diperhatikanolehguruyaitubagaimanapenilaia $\mathrm{n}$ dalampembelajaran matematikalebih sistematis dan logis untuk mengungkapkan dan menilai peserta didik secara komprehensif, objektif, akurat, dan sesuai dengan bukti-bukti yang dimiliki yang sesuai dengan tujuan pembelajaran.

Agar penilaian dapat mengambil tindakan untuk meningkatkan pembelajaran 
atau meningkatkan hasil pembelajaran, penilaian harus menghasilkan sebanyak mungkin informasi yang berkaitan dengan pembelajaran, termasuk informasi formal dan informal. Oleh karena itu, untuk mengumpulkan informasi tentang kemajuan belajar peserta didik baik yangberhubungan dengan proses belajar maupun hasil belajar. Salah satu teknik penilaian yang dapat digunakan untuk melihatperkembangan peserta didi yaitu penilaian portofolio.

Pada dasarnya portofolio digunakan sebagai model pembelajaran bagi guru agar peserta didik dapat mengekspresikan dirinya sendiri maupun sebagai individu atau kelompok.Menurut Sani (2016: 291) portofolio berupa kumpulan dokumen hasilkerja yang menunjukkan kemampuan atau kompetensi seseorang. Kemampuan tersebut berupa kumpulan pekerjaan yang diperoleh melalui pengalaman belajar sehingga mereka dapat menyusun informasi yang mereka temukan, melaporkan dan menuliskan ide-idenya, dan kemudian menuangkannya ke dalam pekerjaan mereka. Dalam hal ini peserta didik dituntut untuk berpikir cerdas, aktif, inovatif, terlibat, menjanjikan dan bertanggung jawab.

Cole, Ryan\& Kick (Suraprana \& Hatta, 2007: 46) mengemukakan bahwa pada hakekanya terdapat dua bentuk portofolio, yaitu portofolioproses dan portofolio produk. Portofolio proses adalah portofolioyang menekankan padabagaimana peserta didik belajar, berkreasi, termasuk dari mulai draff awal itu terjadi dantentunya sepanjang peserta didik dinilai. Sebaliknya portofolioproduk hanya menekankan pada penguasaan (materi) dari tugas yang di tuntut dari suatustandar kompetensi, kompetensi dasar dan sekumpulan indikator pencapaian hasil belajardan hanya menekankan pada evidence yang cukup baik tanpa memperhatikan bagaimanadan kapan' evidence' tersebut diperoleh.

Berdasarkan bentuk uraian tersebut maka peneliti menggunakan bentuk portofolio produk dengan maksud mengungkap perkembangan koneksi matematis peserta didik pada pembelajaran matematika dengan menggunakan pendekatan matematika realistik. Adapun portofolio produk yang digunakan dalam penelitian ini adalah portofolio tampilan dan portofolio dikumentasi.Tujuan penelitian ini adalah 1) untuk mendeskripsikan kemampuan koneksi matematis peserta didik melalui pendekatan pembelajaran matematika realistik yang memiliki Bentuk Portofolio?; dan 2) untuk mendeskripsikan hambatan dan solusi yang ditemui saat mengembangkan kemampuan koneksi matematis peserta didik melalui pendekaan pembelajaran matematika realistik dan Bentuk portofolio?.

\section{Metode}

Jenis penelitian ini adalah penelitian deskriptif kualitatif. Subjek penelitian ini adalah seluruh peserta didikkelas V SDN 8 Pinrang berjumlah30 peserta didik pada tahun akademik 2019/2020.Teknik pengumpulan data yang akan dilakukan melalui teknik tes, observasi partisipatif,dan wawancara dan dokumentasi.

Teknik analisis data yang digunakan dalam penelitian ini adalah secara deskriptifterhadap data kualitatifberupa lembar observasi, hasil wawancara dan dokumentasi.Selain data kualitatif peneliti juga menggunakan data kuantitatif berupa hasil kemampuan koneksi matematis peserta didik melalui Pendidikan Matematika Realistik (PMR) dilakukan denganpenilaian dengan bentuk Portofolio.Penilaian dilaksanakan dengan bentuk portofolio dibagi atas dua aspek berdasarkan indikator kemampuan koneksi matematis yakni; 1) aspek internal dilakukan dengan bentuk portofilio tampilan dan 2) aspek eksternal dengan bentuk portofolio dokumentasi (Hendriana, Rohaerti, \& Sumarno, 2017).

Data kemampuan koneksi matematispeserta didik diperoleh dari penilaian portofolio diukur dan dianalisisdengan menggunakan rumussebagai berikut.

$\mathrm{S}_{\mathrm{K}}=\frac{\sum K}{\sum N} x 100$

Keterangan:

$\mathrm{S}_{\mathrm{K}} \quad$ : Kemampuan koneksi matematis 
$\sum \mathrm{K}:$ Jumlah Skor koneksi matematis $\sum \mathrm{N}$ : Jumlah Skor maksimal

Adapun kriteria penilaian kemampuan koneksi matematis peserta didik adalah sebagai berikut.

Tabel 1. Kategori Kemampuan Koneksi Matematis

\begin{tabular}{cc}
\hline Persentase penilaian & Kategori \\
\hline $85 \mathrm{~K}<100$ & Sangat Baik \\
$70 \mathrm{~K}<85$ & Baik \\
$55 \mathrm{~K}<70$ & Cukup Baik \\
$40 \mathrm{~K}<55$ & Kurang Baik \\
$\mathrm{K}<40$ Kurang & Kurang \\
\hline
\end{tabular}

(Sumber: Tandiling, 2013)

\section{Hasil dan Pembahasan}

Data kemampuan koneksi matematis peserta didik diperoleh dari hasil penilaian bentuk portofolio. Berikut hasil ini adalah hasil analisis kemampuan koneksi matematis aspek internal peserta didik.

\section{Kemampuan Koneksi Matematis Aspek Internal}

Kemampuan koneksi matematis pada aspek internal diperoleh dengan bentuk portofolio tampilan. Berikut ini hasil kemampuan koneksi matematis peserta didik.

Tabel 2. Hasil Kemampuan Koneksi

Matematis bentuk portofolio Tampilan

\begin{tabular}{cccc}
\hline Kategori & f & Prosentase & mean \\
\hline Sangat Baik & 10 & $37 \%$ & \\
Baik & 8 & $28,57 \%$ & \\
Cukup Baik & 7 & $25 \%$ & 73,21 \\
Kurang Baik & 2 & $7,14 \%$ & \\
Kurang & 1 & $3,57 \%$ & \\
Jumlah & 28 & $100 \%$ & \\
\hline
\end{tabular}

Mengacu pada tabel 2, diketahui nilai rata-rata kemampuan koneksi matematis peserta didik pada aspek internal sebesar 73,21 , hal ini berarti bahwa dengan memiliki kemampuan koneksi matematis maka peserta didik akan lebih mudah memahami permasalahan matematika dengan lebih komprehensif. Kemampuan tersebut tercermin padakegiatan PMR seperti peserta didik diberikan kesempatan untuk menghubungkan sendiri konseppada materi yang dipelajari dengan hal-hal yang ada disekitar mereka, dengan kata lain guru memfasilitasi dan memberipemahaman mengenai masalah-masalah secara kontekstual dengan meninjau ulang konsep matematika kemudian mengkaitkan berdasarkan pengalaman peserta didik. Pada tahap selanjutnya peserta didik dimintaberdiskusi kemudian menarik kesimpulan dalam menyelesaikan masalah tersebut. Hal ini sejalan dengan Raharjo et al., (2018)bahwa dengan PMR dapat membantu peserta didik untuk lebihaktif dalam pembelajaran.

Untuk mendukung kegiatan PMR dilakukan dengan bentukPortofolio Tampilan yang penilaiannya sesuai dengan aspek kemampuan koneksi matematis peserta didik seperti signifikansi materi yang ingin diketahui dan dipecahkan, tingkat pemahaman disesuaikan denganpeserta didik, pada kegiatan diskusi lebih mengutamakan pada kemampuan dalam mempertahankan argumentasi dan kemampuan memberikan respon terhadap pertanyaan yang diberikan serta partisipasi aktif anggota dalam menumbuhkan tanggung jawab dan kerjasama kelompok.

\section{Kemampuan Koneksi Matematis Aspek Eksternal}

Kemampuan koneksi matematis pada aspek internal diperoleh dengan bentuk portofolio tampilan. Berikut ini hasil kemampuan koneksi matematis peserta didik

Tabel 3. Hasil Kemampuan Koneksi Matematis Bentuk Portofolio Dokumentasi.

\begin{tabular}{cccc}
\hline Kategori & f & Prosentase & mean \\
\hline Sangat Baik & 12 & $42,86 \%$ & \\
Baik & 9 & $32,14 \%$ & \\
Cukup Baik & 5 & $17,86 \%$ & 77,32 \\
Kurang Baik & 2 & $7,14 \%$ & \\
Kurang & - & - & \\
Jumlah & 28 & $100 \%$ & \\
\hline
\end{tabular}

Berdasarkan tabel 3, menunjukkan bahwa kemampuan koneksi matematis peserta didik telah berkembang sangat baik melalui PMR dengan bentuk portofolio 
dokumentasi. Kegiatan tersebut membuat peserta didik sangat senang mengerjakan karyanya yang membutuhkan penyelesaian masalah matematis secara langsung di lapangan, baik dalam rangka mencari bahan maupun menyelesaikan karyanya proses yang agak lama disamping kegiatan tersebut melatih kreativitas peserta didik. Hal ini dikuatkan dengan hasil yang diperoleh peserta didik yakni nilai rata-rata kemampuan koneksi matematis peserta didik pada aspek eksternal sebesar 77,32. Hal ini didukung hasil penelitian yang telah dilakukan oleh Nadar (2016) bahwa dengan bentuk portofolio dokumentasi mempunyai kelebihan dalam penerapannya karena siswa langsung memperoleh bahan-bahan terpilih yang dapat diperoleh dari literature/buku, kliping dari koran/majalah, foto, gambar, grafik, internet, observasi lapangan dan lainlain. Dengan demikian melalui PMR dan bentuk portofolio dapat mengembangkan kemampuan koneksi matematis peserta didik.

\section{Simpulan}

Berdasarkan hasil dan pembahasan pada penelitian ini dapat dipetik kesimpulan bahwa melalui PMR dan bentuk portofolio dapat mengembangkan kemampuan koneksi matematis peserta didik. Penerapan PMR dan bentuk portofolio menunjukkan peserta didik sangat aktif dalam mengerjakan karya atau tugasnya. Peserta didik menjadi menghargai waktu, rapi, dan disiplin serta mengembangkan kreativitasnya.

\section{Daftar Pustaka}

[1] Crompton, H., \& Traxler, J. (2015). Mobile learning and mathematics: foundations, design, and case studies

[2] Kusmaryono, Imam. 2013 Kapita Selekta Pembelajaran Matematika Semarang: UNISSULA.

[3] Linto, R.L, dkk. (2012). Kemampuan koneksi matematis dan metode pembelajaran quantum teaching dengan peta pikiran. Jurnal Pendidikan Matematika. Part 2: Hal. 83-87

[4] Masnur. (2017) Penerapan Metode Role Playing untuk meningkatkan Motivasi dan Hasil Belajar PKN Siswa tentang Musyawarah kelas II di SD.

[5] Nadar. 2016. Pengaruh Pendekatan Matematika Realistik dan Bentuk Portofolio Terhadap Kemampuan Koneksi Matematika. Jurnal Pendidikan Dasar. Volume 7 edisi 2: Hal. 265-282.

[6] NCTM. 2000. Principle and Standards for School Mathematics. Reston, VA: NCTM.

[7] Raharjo, M. S., Azhar, E., \& Faradillah, A. (2018). Pengaruh Model Pembelajaran Realistic Mathemathics Education (RME) Terhadap Kemampuan Penalaran Matematis Siswa. Seminar Nasional Pendidikan Matematika 2018, 01, 19-29.

[8] Sani, Ridwan Abdullah. 2016. Penilaian Autentik. Jakarta: Bumi Aksara.

[9] Tandililing, 2013. Pengembangan Kemampuan Koneksi Matematis Siswa Melalui Pendekatan Advokasi dengan Penyajian Masalah Open-Ended pada Pembelajaran Matematika". Makalah dipresentasikan dalam Seminar Nasional Matematika dan Pendidikan Matematika di Jurusan Pendidikan Matematika, FMIPA UNY,Yogyakarta

[10] Wahyudin, "Pembelajaran Dan Model Model Pembelajaran: Pelengkap Untuk Meningkatkan Pedagogis Para Guru Dan Calon Guru Profesional" (Bandung, 2008) 